\title{
KÜRESELLEŞME KAVRAMI VE KÜRESELLEŞMEYE YÖNELIK YAKLAŞIMLAR
}

\author{
Duygu DUMANLI KÜRKÇÜ \\ İstanbul Kültür Üniversitesi, Sanat ve Tasarım Fakültesi, İletişim Sanatları Bölümü \\ d.dumanli@iku.edu.tr
}

\begin{abstract}
The globalization is a notion which explains the very latest enhancements. Nonetheless it is not possible to reach to a concensus about the outcomes of globalization. In this study, we tried to explain notion of globalization and we analyzed the concepts of it. Then, we studied different approaches with the historical development of the concept.
\end{abstract}

Key Words: Globalization, Localization

\section{1- GİRISŞ}

Küreselleşme, dünyada son zamanlarda yaşanan gelişmeleri açıklamak için kullanılan bir kavramdır. Bu gelişmelerin ekonomik, siyasi, sosyal, teknolojik ve kültürel boyutları olduğu için de küreselleşmenin tanımı ve anlamı kişiden kişiye göre farklılık göstermektedir. Küreselleşmenin sonuçlarına ilişkin de bir görüş birliğinden söz etmek mümkün değildir. Bu bağlamda küreselleşme kavramına ilişkin çeşitli yaklaşımlar bulunmaktadır.

Bazıları küreselleşmenin dünyada refahı arttıracağını, gelişmiş ve gelişmekte olan ülkeler arasındaki farkları azaltacağını ifade ederken bazıları da aynı kavramı sömürgeciliğin modern yaklaşımı olarak ifade etmişlerdir. Küreselleşme kavramına ilişkin bir yandan olumlu yaklaşımlar varken (Aşırı Küreselleşmeciler), diğer yandan da bu süreci çok şiddetli bir şekilde eleştiren olumsuz yaklaşımlar (Küreselleşme Karşıtları) bulunmaktadır. Ayrıca küreselleşme sürecine daha tarafsız yaklaşan (Dönüşümselci) görüşler de bulunmaktadır.

Bu çalışmada öncelikle küreselleşme kavramını açıklamaya yönelik çeşitli tanımlamalara yer verilmiş, küreselleşme kavramının tarihsel süreçteki gelişimi açıklanmış, sonrasında küreselleşme kavramına yönelik yaklaşımlara yer verilerek bu yaklaşımların tarihsel değerlendirmeleri açıklanmıştır. Buradan da yola çıkılarak küreselleşme ve yerelleşme arasındaki ilişki irdelenmeye çalışılmıştır. ${ }^{*}$

\section{2- KÜRESELLEŞME KAVRAMI}

Küreselleşme kavramı, başta akademik ve ekonomik çevrelerde olmak üzere en çok tartışılan kavramların başında gelmektedir. Özellikle akademik çevreler tarafindan küreselleşmenin ne olduğu, küreselleşmeyi ortaya çıkaran sebepler ve küreselleşme sürecinin sonuçları, küreselleşmenin olumlu ve olumsuz yönleri de farklı düşünce kalıplarıyla ele alınarak açıklanmaktadır. Bu bağlamda küreselleşme kavramı ve küreselleşme sürecine ilişkin birçok tanım ve açıklama yapılmıştır.

George Modelski, "küreselleşme dünyanın büyük medeniyetleri arasındaki artan bağlantının tarihidir” der. Küreselleşme kavramı en eski medeniyetler arsında düzensiz aralıklarla ortaya çıkan karşılaşmalara kadar uzanan, uzun vadeli tarihsel bir süreçtir. Modelski'ye göre küreselleşme, uluslar, medeniyetler ve siyasal topluluklar arasındaki genel dayanışmanın genişlemesinin ve derinleşmesinin tarihsel sürecini kapsayan bir kavramdır(Held ve McGrew, 2008:71). Küreselleşmenin fikir mimarları Muray Rohtbard ve David Friedman gibi liberal düşünürlerdir. $\mathrm{Bu}$ düşünürler 1970'li yıllardan itibaren 'piyasaların serbestliği ilkesi'ni

\footnotetext{
* İstanbul Üniversitesi Gazetecilik Anabilim Dalı Doktora Programı, Küreselleşmenin Medya Etkileri dersi ödevi olarak hazırlanmıştır. Çalışma yayınlanmak üzere genişletilip revize edilmiştir.
} 
çalışmalarının merkezine koymuşlar böylece 'bırakınız yapsınlar' şeklindeki liberal ideolojinin geçerliliğini kanıtlamaya çalışmışlardır. Söz konusu liberal söylem kaynağını, Ludwig von Mises ve Friedrich von Hayek'in temsil ettiği Macar Ekonomi Okulu düşünürlerinden almaktadır(Tutal,2006:22-23).

Küreselleşme; uluslararasılaşma sürecinin tamamlanıp, bölgesel olmayan üretim dokularının üretim ve tüketiminin dünya ölçeğinde planladığı, serbest rekabet ve piyasa düzeninin uluslarüstü kuruluşlar tarafından denetlendiği, kuralların uluslarüstü anlayışla çalıştığı bir sistemdir(Kutlu, 1998:175).

Küreselleşme kavramının hangi unsurları içermesi gerektiği konusunda ortak bir kanı olmamasına rağmen, genel olarak kabul gören bir biçimi olarak şu tanımlama yapılabilir; "küreselleşme; insan, sermaye, teknoloji ve hizmetler bakımından entegrasyonun sağlanmasıdır. Küreselleşme; ticaretin, direkt yabancı sermaye yatırımlarının artması ve fikir haklarının uygulamaya konmasıyla üretim faktörlerinin mobilitesinin daha da yükselmesi sonucu dünyanın giderek daha fazla bütünleşmesini ifade etmektedir"(Adams, 2008:725). Küreselleşme kavramına ilişkin diğer bir tanımda şu şekildedir; küreselleşme toplumların siyasal yönetimi ve yönetim politikaları, ideolojisi ve kültürleri üzerinde uluslararası sermayenin ekonomik politikası, kültürü ve ideolojisinin egemenliğini kurması ve geliştirmesidir(Gezgin,2005:10).

Giddens'a göre küreselleşme modernlik kavramıyla geniş çapta eşanlamlıdır. Çünkü yeni çağda 'dünya çapında toplumsal ilişkilerin yoğunluğu' daha önceki tarihsel dönemlerin hepsinde olduğundan çok daha fazladır. Küreselleşmeyi anlamak için modernliği güdüleyen güçleri incelemek gerekmektedir; yani iç içe geçmiş sanayileşme, kapitalizm, militarizm ve devletçilik süreçlerinin nitelikleri gereği nasıl küreselleşen bir güce sahip olduklarını anlamak gerekmektedir(Held ve McGrew,2008:71-72).

Giddens'a göre toplumsal etkinliğin küreselleşmesi, bazı açılardan, gerçek anlamda dünya çapında bağlantıların, örneğin küresel ulus-devlet sistemiyle veya uluslararası işbölümüyle ilişkili bağlantıların gelişmesi sürecidir. Bununla birlikte, genel düzeyde küreselleşme, en iyi şekilde, zamansal-mekansal uzaklaşmanın temel boyutlarının bir ifadesi olarak anlaşılmaktadır(Giddens,2010:37). Paul Hirst ve Grahame Thompson küreselleşme kavramı ve süreci ile ilgili görüşlerini şu şekilde açıklamışlardır; ulusal kültürlerin, ulusal ekonomilerin ve ulusal sınırların çözüldüğü, sosyal hayatın büyük bir bölümünün küresel süreçler tarafından belirlendiği bir çağda yaşıyoruz. Bu anlayışın temelinde, yeni ve hızlı ekonomik küreselleşme süreci fikri yatmaktadır. Ayrı ulusal ekonomilerin ve dolayısıyla ulusal ekonomik yönetimin yerli stratejilerinin hızla geçerliliğini kaybettiği gerçek bir küresel ekonominin ortaya çıktı̆̆ ya da çıkma sürecinde olduğu öne sürülmektedir(Hirst ve Thompson, 2007:26).

Küreselleşme kavramına ilişkin çalışmalarda bulunan David Held ve Anthony McGrew küreselleşme için özel bir kavramsallaştırmayla birlikte küreselleşmenin özelliklerini keşfetmek amaçlı kullanılacak yöntemler dizisi sunmuşlardır.

David Held ve Anthony McGrew, küreselleşmeyi; 'kıtalar arası veya bölgeler arası akışlar ve ağlar meydana getiren, toplumsal ilişkilerin uzamsal örgütlenmesinde dönüşümü temsil eden bir süreç' olarak tanımlamaktadırlar(Held ve McGrew,2008:72).

Robertson ise, küreselleşme sürecinin bir yüzünü küreselin yerelleşmesi, diğer yüzünü ise yerelliklerin evrenselleşmesinin oluşturduğunu belirtmektedir. Küresel ve yerel arasında süregelen karşılıklı dinamiğin sonucu olarak yaşanan farklılaşma ve aynılaşma birbirini olanaklı hale getirmektedir. Robertson'a göre yerelliği yaratmak ve daha sonrada içermek olarak tanımlanan bu süreç küreselleşme kavramı ile somutlaşmaktadır(Öngören, 2002:449). 
Robertson, küreselleşme sürecini kapsayıcı bir biçimde açıklamaya çalışırken öncelikle sosyo-kültürel süreçleri ön plana almaktadır. Robertson'a göre küreselleşme olgusu kendisini oluşturan toplumsal, kültürel ve ekonomik süreçlerden bağımsız değildir. Küreselleşme, modernitenin dinamizmine özgü bir dizi süreçten meydana gelmektedir ve kavram olarak da dünyanın küçültülmesi ve bir bütün olarak dünya bilincinin pekiştirilmesini ifade etmektedir(Ilgaz Büyükbaykal,2004:8). Paul Hirst ve Grahame Thompson'a göre küreselleşme süreci ile birlikte dünya ekonomisi temel dinamikleri itibari ile uluslararasılaşt1, denetim dışı piyasa güçleri tarafından baskı altına alındı, hiçbir ulusal devlete tabi olmayan ve piyasa avantajlarının belirlediği yerlere yerleşen gerçek ulusötesi şirketler oldu(Hirst ve Thompson, 2007:26).

Özetle belirtmek gerekirse küreselleşme, her alanda mesafenin daha az önemli hale gelmesi, siyasal, ekonomik, sosyal ve kültürel alanlarda dünyanın daha çok bütünleşmesi süreci olarak da ifade etmek mümkündür. Bu bağlamda küreselleşme tek taraflı bir süreç değildir, daha çok çift taraflı bir süreçte, zıt eğilimleri içererek de gelişmektedir.

\section{3- KÜRESELLEŞMENIN TARİHSEL SÜREÇTEKİ GELIŞSIMİ}

Küreselleşmeyi ülkeler arasında büyük ve artan bir ticaret akışıyla, sermaye yatırımının gerçekleştiği açık bir uluslararası ekonomi olarak tanımlanırsa, bu tarz bir işleyiş uluslararası ticari faaliyetlerin tarihi bakımından yeni olmamaktadır. Gerçek anlamda bütünleşmiş bir dünya ticaret sistemi, 19. yüzyılın ikinci yarısından itibaren vardır. Ekonomik olayların küreselleşmesinin ve bunun oluşturduğu yeni durumun genellikle 1960'larda ortaya çıktığı düşünülmektedir. 1960 bir taraftan küresele kurumların ortaya çıktığı ve küresel düzeyde faaliyetlerini sürdürdüğ̈̈, diğer taraftan da ticari faaliyetlerin hızla gelişim gösterdiği bir dönemdir(Çubukçu,1999:7).

Küreselleşmenin tarihi gelişim sürecini irdeleyecek olursak öncelikli olarak İkinci Dünya Savaşı sonrası Soğuk Savaş dönemi ve bu dönemde ki ekonomik ve toplumsal olguları göz önünde bulundurmak gerekmektedir. Genel olarak küreselleşme süreci, Soğuk Savaş'ın sona ermesi ve Sosyalist Blok'un çökmesiyle birlikte büyük bir hız kazanmıştır.

Sovyet Birliği dağılmadan önce dünyada bir tarafta ABD diğer tarafta ise Sovyet Birliği'nin yer aldığı iki kutuplu bir denge söz konusudur. Sovyet Birliği'nin dağılması süreci ile birlikte dünya üzerindeki bu denge bozulmuştur. Sovyet Blok'unun giderek küreselleşen dünya ekonomisi ve teknoloji karşısında, rekabet edememesi iki kutuplu dengenin dağılmasına neden olmuştur. 1945 yılına bakıldığında bir tarafta savaş öncesine oranla askeri ve ekonomik gücünü kaybeden Avrupa devletleri, diğer tarafta ise dünyanın süper güçleri niteliğinde $\mathrm{ABD}$ ve Sovyetler Birliği yer almaktadır. Batı'da ABD ekonomisine bağlı olarak yeniden yapılanan liberal demokrasileri Doğu'da ise komünist ideolojiye sahip bir ekonomik-siyasi güvenlik sahas1 oluşturan Sovyetler Birliği'nin varlığı söz konusu olmaktadır(Ilgaz Büyükbaykal,2004:16). Suat Gezgin'e göre küreselleşme sürecine hız kazandıran faktörlerden biri de Doğu Bloku'nun yıkılması sonrasında liberal piyasa ekonomisine yönelik güven duygusunun artmasıdır. Bu bağlamda kısa bir sürede devletçi ekonomiler tüm maliyetlerine rağmen terk edilmeye başlanarak, serbest ekonominin imkanlarından yararlanma çabası içine girmişlerdir. Söz konusu durum teknolojinin üretimini ve dağıtımını elinde tutan ülkeler için yeni pazarlar kazanmak anlamına gelmektedir(Gezgin,2005:11).

1945-1975 yılları arasında dünya coğrafi mekan olarak önemli bir bölümünü serbest Pazar ilişkilerine açmıştır. "1945 öncesinden temelde farklı bir dünya ticareti alanı ortaya çıktı. İleri kapitalist ülkelerdeki sermaye kendine daha serbestçe at koşturabileceği bir zemin buldu. Serbest Pazar ekonomisine, kapitalizme geçen ülkeler arttı veya bir başka deyişle "üçüncü dünya" denilen ülkelerde kapitalizmin gelişmesi hızlandı. Kısacası bu dinamiği 1980'lerden itibaren şekillenecek olan küreselleşmeyi hazırlayan en önemli gelişmelerin birincisi olarak kabul edebiliriz" (Ilgaz Büyükbaykal,2004:19). 
1970’li yıllarda gelişmiş ülkelerin ekonomilerinde bir durgunluk dönemi ortaya çıkmıştır. Gelişmekte olan ülkeler de ortaya çıkan bu bunalımdan payları almışlardır. Ancak bu bunalımın etkileri gelişmekte olan ülkelerde daha çok 1980'lerde görülmektedir. Bu dönemde bir çok ülke dalgalı döviz kuru sistemini kabul etmiştir (Ilgaz Büyükbaykal,2004:19).

1980'li ve 1990'lı yıllarda ekonominin uluslararasılaşması ve bloklaşmaların artması, dünyanın ekonomik, teknolojik ve kültürel coğrafyasını yeniden şekillendirmiştir. Ayrıca dünya siyasi eğilimindeki yumuşama yeni pazar imkanlarının bölgesel işbirlikleri ve bütünleşmelerin yoğunlaşmasını sağlamakta ve tüketim yapısında değişmelere yol açmaktadır. Ekonominin uluslararasılaşmasında geleneksel anlamdaki ürünler yerine, değişik ulusların katılımıyla ortaya konulan ürünler ve ulusal pazar yerine uluslar aşırı pazarlar mevcuttur. Bu pazarda değişik kültürlere sahip tüketicilerin zevk ve tercihlerinden oluşan veya oluşturulan "homojenlik", "dünya tüketim kültürünün" oluşmasına ve gelişmesine yol açmıştır. Kurumlar, ülkeler ve kültürler arasındaki farkları aşarak küresel çapta oluşan bu istek ve ihtiyaçların tatminine çalışmaktadırlar(Şığya, 2001:8-9).

Manuel Castells'e göre, 1980'lerin sonlarında, 1990'ların başlarında iktidara gelen yeni liderlerin siyasi çıkarları da küreselleşme seçeneğini destekliyordu. Castells'in siyasi çıkarlardan kasıt ettiği ise, seçilmek ve iktidarda kalmaktır. Birçok durumda yeni liderler, ekonomilerin inişe geçmesi, hatta çoğu zaman çökmesi sonucu seçilmiştir ve iktidarlarını ülkenin ekonomik performansını ciddi biçimde geliştirerek güçlendirmişlerdir. Castells bu duruma örnek olarak 1992'de seçilen Clinton'1 vermektedir. Castells, Clinton'ın başarılı başkanlık kampanyasının "Mesele ekonomi, aptal!" söylemi etrafında örgütlendiğini vurgulamıştır(Castells, 2005:180-181).

Joseph Stiglitz'in “Küreselleşme büyük hayal kırıklığı” adlı kitabında, Clinton'ın Ekonomik Danışmanlar Konseyi'nin başkanı olarak, devlet ve piyasalar arasındaki ilişkiyi, birbirini bütünleyen bir ilişki olarak gören, her ikisinin de ortaklaşa çalıştığını kabul eden bir ekonomi politikası ve felsefe oluşturmaya çalıştığını ve piyasalar ekonomisinin merkezinde yer alsa bile devletin oynayacağ belirtmiştir(Stiglitz,2002:13).

Roland Robertson ise küreselleşmenin beş farklı evreden geçip günümüze geldiği tezini savunmaktadır. Robertson, birinci evreyi oluşum evresi, ikinci evreyi başlangıç, üçüncü evreyi yükseliş, dördüncü evreyi hegemonya için mücadele, beşinci evreyi ise belirsizlik evresi olarak adlandırmıştır. Roland Robertson, bu evreleri şu şekilde açıklamıştır(Özkan,2004:18-19):

Küreselleşmenin oluşum evresi Avrupa'da onbeşinci yüzyılın başlarından onsekizinci yüzyılın ortalarına kadar sürmüştür. Bu evrede ulus topluluklar yavaş yavaş ortaya çıktı ve Ortaçağ'ın ulusötesi sistemi çöktü. Katolik kilisesinin etkinlik alanı genişledi. Birey anlayışları insanlığa ilişkin düşünceler öne çıktı. Küreselleşmenin başlangıç evresi ise Avrupa'da onsekizinci yüzyılın ortasından 1870'lere kadar sürdü. Başlangıçta üniter devletler düşüncesi doğrultusunda keskin yön değişiklikleri oldu. Resmi uluslar arası ilişkiler anlayışı gelişti, birey bilinci oluştu, çok daha somut bir insanlık anlayışı yerleşti. Uluslararası ve ulusötesi düzenlemeler ve iletişime ilişkin yasal sözleşmeler yapıldı.

1870 ve 1920 arası, küreselleşmenin yükseliş evresi oldu. Bu dönemde "modernlik" sorunu ilk kez temalaşmaya başlandı. Ulusal ve kişisel kimliklere ilişkin düşünceler ortaya çıktı, Avrupalı olmayan birkaç toplum "uluslararası topluma" kabul edildi. İletişimin küreselleşmesi artt1, küresel yarışmalar devreye girdi, Olimpiyatlar ve Nobel ödülü gibi. Robertson'un küreselleşmenin dördüncü evresi olarak tanımladığı "Hegemonya için mücadele" evresi 1920'lerin ortalarında başladı ve 1960'lı yıların sonuna kadar sürdü. Milletler Cemiyeti ve ardından da Birleşmiş Milleteler kuruldu. Ulusal bağımsızlık ilkesi kabul edildi. Çatışan “modernlik anlayışları” belirdi. Üçüncü Dünya belirginleşmeye başladı. 
Robertson, küreselleşmenin beşinci evresi olarak tanımladığı "belirsizlik evresi” ise 1960'ların sonunda başladı. 1990'ların başında krize girdi. Bu evrede soğuk savaş sona erdi ve "hak ve özgürlükler" teması öne çıkmaya başladı. Küresel kurum ve hareketleri çoğaldı, kitle iletişim araçlarının sayısı, hızı ve yaygınlığı akılalmaz derecede arttı. Toplumlar çokkültürlülük ve çoketniklik sorunuyla bu evrede daha fazla karşılaştılar. İnsan Hakları küresel bir sorun haline geldi, uluslararası sistem daha fazla akışkanlık kazandı.

\section{4- KÜRESELLEŞMEYE YÖNELİK YAKLAŞIMLAR}

Küreselleşme kavramına yönelik düşünce ve yaklaşımları çok genel bir tanımlamayla, yeni dünya düzeninden memnun olanlar ya da olmayanlar şeklinde açıklamam mümkündür. Ayrıca bu açıklamaya ek olarak bu iki aşırı uç arasında küreselleşme bir abartıdır tezini savunanlarda bulunmaktadır.

Küreselleşme süreç ve yaklaşımlarına yönelik çalışmalar literatürde ikili, üçlü ve dörtlü gruplandırmalar şeklinde karşımıza çıkabilmektedir. Ancak küreselleşme konusunda çalışan araştırmacıların genellikle küreselleşmeye yönelik tutum ve değerlendirmelerini, Held ve McGrew'ın çalışmasında sunduğu üçlü gruplandırma şeklinde gerçekleştirdikleri söylenebilir(Bryane:4).

Held ve McGrew'ın çalışmasında küreselleşmenin;

1-Aşırı Küreselleşmeci Yaklaşım (Hiperglobalist),

2-Kuşkucu Yaklaşım (Sceptic)

3-Evrimsel-Dönüşümsel Yaklaşım (Transformationalist) olmak üzere üç yaklaşımı içerdiği belirtilmektedir.

Aşırı Küreselleşmeci Yaklaşım (Hyperglobalist), bir yandan daha önce gerçekleşmiş önemli gelişmeleri inkâr etmezlerken; diğer yandan aynı dönemde olan (yani güncel, modern) küreselleşme belirtilerinin ortaya çıktığı belli tarihsel kırılma noktalarını da tayin ederler. Onlara göre eski çağlar, ön-küreselleşme (pre-globalisation) dönemi olarak adlandırılmıştır.

Kuşkucu Yaklaşımı Benimseyenler (Sceptic); küreselleşmenin ve küresel bağlantıların yeni birer olgu olmadığını vurgulayarak konuyu ele alırlar. Küreselleşme kuşkucuları; küreselleşmenin yüzy1llar boyunca sürmekte olduğunu, bazı gelişmelerin küreselleşmenin sadece derecesini ve kapsadığı alanı değiştirdiğini ancak olgunun tek başına öz karakteristiği olmadığını belirterek kültürel, ekonomik, politik, sosyal ve teknolojik gelişmeleri evrimsel bir çizgiye dayandırırlar.

Dönüşümsel Yaklaşım (Transformationalist) tezini savunanlar; küreselleşmenin kendisinin başlı başına, modern toplumları ve dünya düzenini tekrardan şekillendirerek yapılandıran, yaygın sosyal, politik ve ekonomik değişimlerin hızını belirleyen temel güç olarak görürler. Dolayısı ile aşırı küreselci yaklaşımı radikalleştirirler. Küreselleşmeye yönelik tüm bu yaklaşımlar, güncel olan küreselleşme olgusuna etki eden anahtar unsurlar olarak farklı faktörleri görerek bunlar üzerine odaklanırlar. Dolayısıyla her yaklaşım kendi küreselleşme tanımını yapmaktadır(Rennen ve Martens,2003:137).

\section{4-1- Aşırı Küreselleşmeciler}

Aşırı küreselleşmecilere göre küreselleşme, insanlık tarihinde geleneksel ulus devletlerin özelliklerini yitirdiği ve hatta küresel ekonomide işlevsiz bir birim haline geldiği yeni bir çağ ifade etmektedir. Aşırı küreselleşmeciler, ekonomik küreselleşmenin uluslararası üretim, ticaret ve finans ağları oluşturarak milli ekonomilerin yapılarını bozduğunu vurgularlar. $\mathrm{Bu}$ sınırsız ekonomide, yerel hükümetler küresel ve güçlü kuruluşlar arasında işlemlerin aktarımında rol üstlenir hale gelmişlerdir. Birçok aşırı küreselleşmeci, ekonomik küreselleşmenin yeni formlarda sosyal örgütler meydana getirdiğini ve bunlar aracılığıyla da 
geleneksel milli hükümetlerin yerini ele geçirildiğini kabul ederler(Held ve McGrew,2008:14$15)$.

Aşırı küreselleşmeciler, küreselleşme söyleminin Batı'daki güçlü toplumsal güçlerinin çıkarlarına hizmet ettiğini reddetmezken, aynı zamanda modern toplumsal örgütlenme ölçeğindeki gerçek yapısal değişimleri de yansıttığını vurgularlar. Diğer gelişmelerin yanı sıra, çok uluslu kurumların artışı, dünya mali piyasaları, popüler kültürün yayılması ve çevrenin küresel olarak yok oluşu bunun kanıtıdır.

Aşırı küreselleşmeci anlayışta merkezi olan, küreselleşmeye atfedilen özgül mekansallıklara yapılan vurgudur. Küreselleşmeci analiz küresel ağları ve sistemleri işleyen diğer mekansal ölçeklerden yerel veya ulusal ayrıştırmaya çalışırken küreselleşmeyi öncelikle bölgeler arası veya kıtalar arası ölçekte buluşturan aktiviteler ve ilişkiler olarak tanımlar(Held ve McGrew,2008:14).

Aşırı küreselleşmecilere göre, piyasalar artık devletlerden daha güçlü konumdadır. Devletlerin otoritesindeki bu gelişme ise, diğer kurumlar ile birliklerin ve yerel-bölgesel otoritelerin artarak yaygınlaşması ş̧eklinde görülebilir. Aşırı küreselleşmeciler, dünya toplumunun, geleneksel ulus devletlerin yerini almakta olduğu ya da alacağı ve yeni toplumsal örgütlenme şekillerinin belirmeye başladığı düşüncesindedirler. Ancak bu grup içinde yer alanlar homojen değillerdir(Hablemitoğlu, 2004:20). Aşırı küreselleşmeciler kendi aralarında farklılık gösterirler. Neoliberallere göre bireysel otonomilerin ve piyasa ilkelerinin devlet gücüne üstünlüğü memnuniyet vericidir. Radikaller ya da Neo-Maksistler için modern küreselleşme ezici küresel kapitalizmin galibiyetini temsil eder(Held ve McGrew,2008:30$31)$.

Hablemitoğlu bu konuya ilişkin olarak şu örneği vermeketedir; Neoliberaller, devlet gücü üzerinde piyasanın ve bireysel özerkliğin başarısını hoşnutlukla karşılarken, aynı grup içinde yer alan Neo Marksistler ya da radikaller, çağdaş küreselleşmeyi, baskıcı kapitalizmin temsilcisi olarak değerlendirmektedirler. Ancak bu ideolojik yaklaşımlardaki farklılıklara rağmen, bugün giderek artan bir biçimde bütünleşmiş küresel bir ekonominin varlığına ilişkin bir fikir birliği de vardır(Hablemitoğlu, 2004:21).

Aşırı küreselleşmeciler, bu sürecin küresel ekonomide kaybedenler kadar kazananları da yarattığına inanıyorlar. Buna rağmen hükümetler, küreselleşmenin sosyal sonuçlarını idare etmek durumunda kalmaktadırlar. Küreselleşme, kazanan ve kaybeden arasındaki kutuplaşmayı, küresel ekonomik düzen içinde birbirine bağlayabilir. En azından neoliberal harekete göre, küresel ekonomik rekabetin "sıfır toplamlı" üretimde bulunması söz konusu değildir. Aşırı-küreselleşmeci bakış açısına göre, küresel ekonominin yükselişi, radikal yeni dünya düzeninin bir kanıtı olarak yorumlanabilecek, küresel düzeyde kültürel karışım, küresel yayılma ve küresel yönetişim kurumlarının doğuşu, köklü bir biçimde yeni dünya düzenin kanıtları ve ulus devletin ölümü olarak yorumlanmaktadır (Bozkurt,http://www.makaleler.com/bilim-makaleleri/kuresellesme-kavram-gelisim-veyaklasimlar.htm: 20.03.2013).

Aşırı küreselleşmeciler, artık ulusal hükümetin sınırlarını kontrolde zorluk çekmeye başladıklarını belirtmişlerdir. Aşırı küreselleşmecilere göre, ülkeler arasında uluslararası işbirliği kolaylaşmıştır; artan küresel iletişim altyapısı sayesinde farklı ülkelerin halkları, ortak çıkarlarının daha çok farkına varmakta ve bunun sonucunda da küresel bir uygarlığın doğuşu için ortak bir zemininin oluşmaktadır.

\section{4-2- Küreselleşme Karşıtları (Kuşkucular)}

David Held ve arkadaşlarınca küreselleşme kuşkucuları olarak tanımlanan bu grup "küreselleşme karşıtları" olarak da ifade edilebilir. Küreselleşme karşıtları için, küreselleşme kavramının kendisi şüpheli olarak görülmektedir. Küreselleşme karşıtları, küreselleşme kavramı içerisinde küresel olan nedir diye sorgulamaktadırlar. Küreselleşme karşıtlarına göre, 
eğer küresel evrensel bir dönüşüm olarak yorumlanamazsa, bu durumda küreselleşme kavramı özgünlük içermekten yoksun olduğu anlamına gelemektedir. Hiç bir coğrafya referans olmadan ulus-ötesini küresel olandan hatta bölgeselleşme sürecini küreselleşme sürecinden ayırmak mümkün görülmemektedir. Diğer bir deyişle, küreselleşme literatürünün çoğu, küresel için mekansal referansları belirtmekte başarısız olduğu için küreselleşme karşı1tları, kavramın deneysel olarak işler duruma getirilemeyecek kadar geniş olduğunu ve bu nedenle, çağdaş dünyayı anlamak için eksik bir araç olduğunu ileri sürmektedirler(Held ve McGrew,2008:11).

Anthony Giddens ise küreselleşmeyi baştan sona tartışmalı olarak gören ve küreselleşmeyle önceki dönemlerde mevcut olana herhangi bir katkı yapılmadığını ifade eden bu grup için "şüpheciler" kavramını kullanmıştır(Giddens, 2010:38). Küreselleşme karşıtı denildiğinde akla ilk gelen isimler Naomi Klein ve Noreena Hertz'dir. Ayrıca Paul Hirst, Graham Thompson, Joseph Stiglitz, Michael Hardt, Antonio Negri, gibi isimlerde küreselleşmeyi büyük ölçüde eleştirenler arasındadır.

Joseph Stiglitz'e göre, küreselleşmenin kendisi iyi ya da kötü değildir. Stiglitz, küreselleşmenin doğru değerlendirildiği zaman iyilikler yapabilecek güce sahip olduğunu belirtmektedir. Küreselleşmeyi kendi koşullarında, kendi hızlarında benimseyen Doğu Asya ülkeleri için küreselleşme, 1997 yılının yol açtığ 1 gerilemeye karşın büyük fayda sağlamıştır. Ancak, dünyanın büyük bölümünde bununla karşılaştırabilecek bir fayda getirmemiştir. Stiglitz'e göre, küreselleşme birçokları için tam anlamıla bir felaket gibi görünmektedir(Stiglitz,2002:42).

Hirst ve Thompson, "Küreselleşme Sorgulanıyor" adlı kitabında bütünleşmiş bir dünya düzeninin bulunmadığını daha çok ülke ekonomilerinden oluşan bir uluslararasılaşmanın söz konusu olduğunu belirtmişlerdir. Hirst ve Thompson'a göre küreselleşmeye dayanak gösterilen birçok ekonomik faaliyet aslında tarihte belli dönemlerde daha yoğun olarak yaşanmıştır ve dolayısı ile küreselleşme gibi bir konunun yeni bir süreci temsil etmediği açıktır. Onlara göre gerçek anlamda uyum sağlamış bir dünya ticaret sistemi 19. yüzyılın ikinci yarısında oluştuğu için, uluslararası ekonominin karmaşık bir açıklık-kapalılık hikayesi vardır(Hirst ve Thompson, 2007:8).

Hirst ve Thompson küreselleşme kavramı üzerine olan iddialarını şu şekilde belirtmişlerdir(Hirst ve Thompson, 2007:27-28);

$>$ Bugünün büyük ölçüde uluslararasılaşmış ekonomisi tarihsel gelişiminden bağımsız değildir. Mevcut uluslararası ekonomi, bazı yönleriyle 1870-1914 yılları arasında hüküm süren rejimden daha az açık ve daha az bütünleşmiştir.

$>$ Gerçek uluslararası kurumlara az rastlanmaktadır. Çoğu kurum ulusal temellidir, ulusal üretim ve satış bölgelerinin gücüne oranla çokuluslu ticaret yapmaktadır.

> Sermaye hareketliliği, gelişmiş ülkelerden gelişmekte olan ülkelere doğru yoğun bir yatırım ve istihdam akışına neden olmamaktadır.

$>$ Bazı iddialı küreselleşme taraftarlarının da kabul ettiği gibi dünya ekonomisi gerçekten küresel olmaktan çok uzaktadır. Ticaret, yatırım ve finansal hareketler daha çok Avrupa, Japonya ve Kuzey Amerika üçgeninde yoğunlaşmış durumdadır.

$>$ Dolayısıyla, eğer politikalarını koordine ederlerse, bu ekonomik güçlerin finansal piyasalar ve diğer ekonomik yönelimler üzerinde güçlü bir yönetişim baskısı kurma potansiyelleri bulunmaktadır.

Joseph Stiglitz küreselleşmeyle ilgili olarak; ulusal devletlerin ulusallaşma sürecini yönlendirdiği gibi küreselleşme sürecini yönlendirebilecek, her ülkenin vatandaşlarına karşı sorumlu davranabilecek bir dünya devletinin bulunmadığını belirtmiştir. Stiglitz'e göre, bunun yerine küresel devletsiz küresel yönetim diye adlandırılabilecek bir sistem mevcuttur, birkaç kuruluş (Dünya Bankası, IMF, WTO) ve birkaç aktörün (belirli mali ve ticari çıkarlara sıkı sıkıya bağlı olan maliye, ticaret ve dış ticaret bakanlıkları) sahneye hakim olduğu ve 
bunların kararlarından etkilenen çok sayıda insanın neredeyse hiçbir söz hakkının olmadığı bir sistem hakimdir(Stiglitz,2002:43).

Hirst ve Thompson küreselleşmiş bir ekonominin sonuçlarını şu şekilde belirtmektedirler (Hirst ve Thompson, 2007:36-39);

> Küreselleşmiş bir ekonominin yönetişimi temel bir açmaz taşımaktadır. Düzenleyicilerin etkin bir işbirliği yürüttüğü ve çıkarlarının örtüştüğü kabul edilse bile, toplumsal koşullarından soyutlanmış küresel piyasaları düzenlemek zordur. Başlıca zorluk, küresel piyasa güçleriyle başa çıkabilecek etkili ve bütünleşmiş uluslararası ve ulusal kamu politikası modelleri oluşturmaktır.

$>$ Çokuluslu şirketlerin, dünya ekonomisinin birincil oyuncuları olarak ulusötesi şirketlere dönüşmesidir. Ulusötesi şirket, uluslararasılaşmış bir yönetimi olan, dünyada en güvenli ya da en yüksek gelirin olduğu yerlere yerleşmeyi uman, özel bir ulusal kimliği olmayan, gerçekten serbest olan sermayedir.

$>$ Küreselleşmenin üçüncü sonucu, örgütlü emeğin ekonomik pazarlık gücünün ve politik etkisinin daha da azalmasıdır. Küreselleşmiş piyasaların ve ulusötesi şirketlerin yansıması, açık bir dünya emek piyasası olacaktır. Bu piyasa, asıl olarak, ülkeden ülkeye gerçek emek hareketliliğyle değil emek maliyeti ve talebi bakımından en uygun bölgeleri seçen hareketli sermayeyle işlemektedir.

$>$ Küreselleşmenin kaçınılmaz sonucu, uluslararası politik sistemdeki çok kutupluluğun artmasıdır. Günümüze kadar hakim durumda olan ulusal güç, kendi topraklarında da başka bir yerde de kendine özgü düzenini zorla kabul ettiremez artık, kamusal ya da özel daha küçük ajanlar hırslı hegemonlara karşı artan reddetme ve sakınma güçlerini kullanırlar. Ulusötesi şirketlerden uluslararası gönüllü kuruluşlara kadar birçok yapı medyayı kullanarak ulusal sınırlar ötesindeki vatandaşlardan meşruiyet ister ve bu meşruiyeti elde eder.

Stiglitz'e göre, küreselleşme baştan şekillendirilebilir. Bu yapıldığında ve gerektiği gibi adil bir biçimde, kendilerini etkileyen politikalarla ilgili bütün ülkelere söz hakk1 verilerek yürütüldügü zaman, hem sürekli ve daha kalıcı bir büyümenin elde edildiği, hem de söz konusu bu büyümenin meyvelerinin daha eşit ve adil bir biçimde bölüşüldüğü bir küresel ekonomi yaratılması sağlanabilir(Stiglitz,2002:43).

Diğer bir bakış açısı ise Avrupa Birliği (bölgecilik/yerellik) umuduna daha fazla dayanması "global" olanlara, "yerel" olanların tepkisidir. Ancak "global" olan karşısında "yerel" olanın tepkiselliği de, muhalefet etme gücü de problemli konumdadır. Küresel ölçekli akışkanlığın şiddeti karşısında, "global" olanla "yerel" olanın gerilimli ilişkisi, ikisinin de biraz birbirine dönüşmesiyle sonuçlanmaktadır. Bu nedenle küreselleşme sürecinin iki yüzü vardır: bir yüzü "evrenselleşme", diğer yüzü "yerelleşmedir". Küresel akışkanlığın yarattığı karşılaşmaların şiddeti karşısında, global olan karşıtını/yereli yaratır, sonra onu içine almaya/yutmaya çalışırken bu süreç içerisinde kendisi de yerelleşir, yerel olan global olana direnirken ya saf bir yerelliği temsil ederek kendi kendini gettolaştıracaktır ya da onunla ilişkiye geçecek, dolayısıyla yerelliğini/farklılığını kaybedecektir. Sonuçta global ile yerel olanların ilişkisi bir dışlama ilişkisi değil, birbirinin içine yerleşme ilişkisidir. Saf (tektipleşmiş̧) bir global ya da saf (tektipleşmiş) bir yerel artık kalmamıştır(Alankuş, 2001:2-3).

Kısaca belirtmek gerekirse küreselleşme kuşkucularına göre küreselleşme, beklenilmeyen bir şey değildir; sadece bu süreç aşırı küreselleşmeciler tarafından abartılarak bir efsane haline getirilmiştir. Dünya ekonomisi geçmişte olduğundan daha az bütünleşmiştir. Küreselleşme, bir bütünleşmeyi değil, farklı kültürler, farklı uygarlıklar ya da bölgeler arasında yeni çatışmaları beraberinde getirecektir. Küreselleşme kuşkucuları ayrıca dünya ekonomisi içerisindeki eşitsizliğe dikkat çekmektedir. 


\section{4-3- Evrimsel-Dönüşümsel Yaklaşımı Benimseyenler}

Evrimsel-dönüşümsel tezi savunanlar arasında; Rosenau, Giddens, Scholte ve Castel bulunur. Modern toplumları ve dünya düzenini şekillendirecek sosyal, politik ve ekonomik değişimlerin merkezinde itici güç olarak küreselleşmenin olduğunu ifade ederler. Dönüşümselcilere göre, küreselleşme aslında çelişkilerle dolu tarihsel sürecinden dolayı bu değişim yönündeki silkelenmenin doğrultusu tahmin edilemez, dolayısıyla belirsizdir.

Giddens'in de dahil olduğu ve "dönüşümcüler" diye nitelendirilen bu üçüncü grup, küreselleşmeyi modern toplumları ve dünya düzenini yeniden şekillendiren hızlı sosyal, siyasal ve ekonomik değişmelerin arkasındaki ana siyasal güç olarak görmektedir.

Aşırı küreselleşmeciler ve küreselleşme karşıtları ile kıyaslandığında dönüşümsel yaklaşım geleceğe ilişkin herhangi bir iddia sunarak küreselleşmenin yörünge haritasını çizmezler. Küreselleşmeye küresel uygarlık veya küresel piyasa bağlamında bakmazlar. Ulus-devletin sonunun geldiğini kabul eden aşırı küreselleşmecilerle aslında bu konuda hiç bir şeyin değişmediğini kabul eden küreselleşme karşıtlarına karşın, dönüşümcüler yeni bir egemenlik rejimi ileri sürerek her iki grubun değerlendirmelerini reddederler. Bu bağlamda bugün egemenlik daha az coğrafi sınırlarla tanımlanmış ve daha karmaşı uluslar üstü ağlarla biçimlendirilmiştir. Dönüşümsel görüş, aşırı küreselleşmecilerin tersine dünyayı tek bir toplum olarak görmez. Daha çok bazı devletlerin, toplumların benzerliklerinin artarak birbirine daha fazla benzer hale geldiğini, ancak bazılarının ise yeni bir küresel seviyede yer alarak gittikçe marjinal hale geldiklerini ifade ederler(Held ve McGrew,2008:8-11).

Evrimsel-dönüşümselciler küreselleşmeyi, modern toplumları ve dünya düzenini yeniden şekillendiren hızlı sosyal, siyasal ve ekonomik değişmelerin aralarındaki güç olarak görmektedir. Artık dış ya da uluslararası ile içişleri arasında açık bir ayrım görülememektedir(Hablemitoğlu,2004:23).

Bu konuda Giddens şu saptamayı yapmaktadır:’Ulus-devletler ve buna bağlı olarak ulusal siyasi liderler hala güçlü müdürler, yoksa dünyayı şekillendiren güçler karşısında büyük ölçüde eli kolu bağlanmış bir konuma mı gelmişlerdir? Ulus-devletler gerçekte hala güçlüdürler ve siyasal liderlerin de dünyada oynayacak büyük bir rolleri vardır. Ama aynı zamanda, ulus-devletin gözlerimizin önünde yeniden şekillenme sürecini de kimse yadsıyamaz"(Esgin:189-190). Aslında bu üç görüş arasındaki temel farklılıklar, olgulardan ziyade, temsil ettikleri dünya görüşlerinden kaynaklanmaktadır. Daha küreselleşme tartışmalarının öncesinde, temelde evrenselci bir tutum içerisinde kendilerini ifade eden liberaller ve bazı Marksistler, küreselleşme sürecini, mevcut yaklaşımların bir sonucu olarak değerlendirmişlerdir(Esgin: 190).

\section{5-SONUC}

Küreselleşme olgusu hangi alanda olursa olsun, ekonomiden sanata, bilimden iletişime herhangi bir çalışmada, yapımda, üretimde, dünyaya açılarak ulusallı̆̆ın, yerelliğin reddedilmeksizin dışına çıkılması ve küreselleşmeyle bağdaştırılmasıdır. Bu bağlamda küreselleşme kavramına ilişkin farklı görüş açıları ve küreselleşme sürecinin tarihsel değerlendirmelerine dair farklılıklar günümüzde de halen devam etmektedir. Bu farklılıkların temelinde küreselleşmeye yönelik yaklaşımların çeşitliliği yatmaktadır. Bu bağlamda küreselleşme yaklaşımlarının vurgulandığı çalışmamızda küreselleşmenin tarihsel değerlendirmeleri David Held ve arkadaşlarının çalışmasında belirtilen üçlü egemen bakış kapsamında yapılmıştır.

Aslında bu üç yaklaşım arasında temel farklılık kaynağı temsil ettikleri dünya görüşleridir. Daha küreselleşme tartışmaları başlamadan önce, temelde evrenselci tutum içinde kendilerini ifade eden liberaller ve bazı Marksistler küreselleşme sürecini, mevcut yaklaşımlarına dayalı olarak değerlendirmişlerdir. Ancak sonuçta zit dünya görüşlerinin temsilcileri olan her iki grup da, ulus devletin ve yerellik unsurlarının aşındığı ve küresel bir uygarlığın doğmakta 
olduğu şeklindeki aşırı-küreselleşmeci bir yaklaşımın benimsendiği benzer görüşleri savunmaktadırlar.

Küreselleşme sürecine eleştirel yaklaşan kuşkucu yaklaşıma göre, küreselleşmenin tarihçesi insanlık tarihinin başlangıcına dayandırılmalıdır. Kuşkucu yaklaşıma göre 1890'lardan daha az bağımsız dünya düzeni vardır. Küreselleşmenin itici gücü bu yaklaşım için devlet ve piyasalardır. Aşırı küreselleşme yaklaşımı taraftarları ise, küreselleşmenin itici gücünün kapitalizm ve teknoloji olduğunu belirtirler ve küreselleşmenin tarihsel sürecini 15 . ve 16 . yüzyıl dolaylarından başlatarak incelemektedirler. 15. yüzyıldan itibaren kapitalist dünya ekonomisinin başlangıcıyla ve dünya üzerindeki coğrafi iş bölümünün, hammaddeye ulaşım imkanlarının, endüstri üretiminin, sermaye dolaşımının artmasıyla birlikte incelenebileceğini vurgularlar. Küreselleşme ile yeni bir çağ algılanması gerektiği vurgulanır. Bu bağlamda ulusdevletin ve yerelliğin gücünün zayıfladığını belirtirler.

Dönüşümsel yaklaşımın savunucuları ise tarihsel değerlendirmelerini 20. yüzyılın son çeyreğinden itibaren gözlenen teknolojik gelişmelerin yansımalarıyla gerçekleştirirler ve küreselleşmenin asıl etkilerinin belki de henüz tam olarak yansımadığını, gelecekte yansıyacağını belirtirler.

Özetle belirtmek gerekirse küreselleşme olgusunun karşısında yerel olanın tepkiselliği de, muhalefet etme gücü de problemlidir. Küresel ölçekli gelişimin şiddeti ve hızı karşısında, küresel olanla yerel olanın gerilimli ilişkisi, ikisinin de biraz birbirine dönüşmesiyle, birbiriyle iç içe geçmesi ile sonuçlanmaktadır. $\mathrm{Bu}$ nedenle küreselleşme olgusunun ve küreselleşme sürecinin iki yüzü bulunmaktadır: bir yüzü "evrenselleşme", diğer yüzü ise "yerelleşmedir". Küreselleşme süreci evrenselleşme (benzeşme) ve yerelleşme (farklılaşma) yönünde iki dinamiği bir arada barındıran, ikisini etkileşime geçiren, sonuçta ikisini de dönüştüren bir süreçtir. Kimi yazarlar bu dönüşümü melezleşme olarak adlandırmaktadır. Artık küresel olanın da yerel olanın da bütün görüntüleri birbiriyle ilişkilenmiş melez görüntüler olarak değerlendirilmektedir.

\section{KAYNAKÇA}

ADAMS, Samuel; "Globalization and Income Inequality: Implications for Intellectual Property Rights”, Journal of Policy Modeling, Vol. 30, 2008.

BÜYÜKBAYKAL, Ceyda Ilgaz; Türkiye'de Televizyon Alanında Küresel Yerel Birlikteliği: CNN Türk ve CNBC-e Örneği, 1. Bask1, İstanbul: İstanbul Üniversitesi İletişim Fakültesi Yayınları, 2004.

BRYANE, Michael; "Theorising the Politics of Globalisation: A Critique of Held et al. Transformationalism", Journal of Economic and Social Research, Vol 4, No.2.

CASTELLS, Manuel; "Enformasyon Çağı: Ekonomi, Toplum ve Kültür, A A Toplumunun Yükselişi”, çev: Ebru Kılıç, 1. Baskı, İstanbul: İstanbul Bilgi Üniversitesi Yayınlar1, 2005.

ÇUBUKÇU, M.İhsan; "Küreselleşme Süreci İçinde Tüketim Toplumu ve Tüketim Kültürü”, (Yüksek Lisans Tezi, Atatürk Üniversitesi SBE, 1999).

DİRLIK, Arif; Küreselleşmenin Sonu mu?, Çev: İsmail Kovacı ve Veysel Batmaz, 1.Baskı, İstanbul: Ayrıntı Yayınları, 2012.

ESGİN, Ali; “Ulus-Devlet ve Küreselleşmeye İlişkin Bazı Tartışmalar”, C.Ü Sosyal Bilimler Dergisi, 2005,cilt:25,No:2,ss:185-192. 
GEZGIIN, Suat; "Küreselleşmenin Medya ve Toplum Üzerindeki Etkileri", İstanbul Üniversitesi İletişim Fakültesi Dergisi, 2005,sayı:21, ss:9-12.

GIDDENS, Anthony; Modernite ve Bireysel-Kimlik Geç Modern Çağda Benlik ve Toplum, 1.Bask1 İstanbul: Say Yayınları, 2010.

HABLEMITOĞLU, Şengül; Küreselleşme Düşlerden Gerçekleri, Ankara: Toplumsal Dönüşüm Yayınları,2004.

HELD, David ve McGREW Anthony; Küresel Dönüşümler Büyük Küreselleşme Tartışması, Ankara: Phoenix Yayınevi, 2008.

HIRST, Paul ve THOMPSON, Grahame; Küreselleşme Sorgulanıyor, 4.Bask1, Ankara: Dost Kitabevi, 2007.

KUTLU, Erol; Dünya Ekonomisi, Anadolu Üniversitesi Basımevi, Eskişehir, 1998.

KIM, Young Yun ve BHAWUK, Dharm P.S; "Globalization and Diversity: Contributions from Intercultural Research", International Journal of Intercultural Relations, 32, 2008.

ÖNGÖREN, Habibe; “Küreselleşme ve Yerel Kültür”, İstanbul Üniversitesi İletişim Fakültesi Dergisi, 2002, cilt:15, sayı:1.

ÖZKAN, Abdullah; Küreselleşme ve Avrupa Birliği İle Bütünleşme Sürecinde Türkiye, 1. Baskı, İstanbul: Tasarım Yayınları, 2004.

RENNEN, Ward ve MARTENS, Pim; "The Globalisation Timeline", Integrated Assessment, 2003, Vol 4, No:3.

STIGLITZ, Joseph E.; Küreselleşme Büyük Hayal Kırıklığı, çev: Arzu Taşçığlu ve Deniz Vural, 1. Baskı, İstanbul: Plan B Yayıncılık, 2002.

ŞIĞVA, Yasemin; "Küreselleşme ve Reorganizasyon İhtiyacı Erzurum Aşkale Çimento Sanayi’de Bir Uygulama”, (Yüksek Lisans Tezi, Atatürk Üniversitesi SBE, 2001).

TUTAL, Nilgün; Küreselleşme İletişim Kültürlerarasılık, 1. Baskı, İstanbul: Kırmızı Yayınları, 2006.

\section{ELEKTRONIK KAYNAKÇA}

Veysel Bozkurt, Küreselleşme: Kavram, Gelişim ve Yaklaşımlar, Elektronik Kaynakça: (http://www.makaleler.com/bilim-makaleleri/kuresellesme-kavram-gelisim-veyaklasimlar.htm).

Sevda Alankuş, Globalleşme, Yerelleşme ve Yerel Medya, Elektronik Kaynakça: (http://bianet.org/bianet/siyaset/218-globallesme-yerellesme-ve-yerel-medya) 